\section{ECONOMICS}

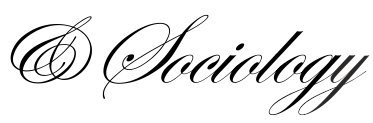

\title{
EXTERNALITIES OF POWER GENERATION IN VISEGRAD COUNTRIES AND THEIR INTEGRATION THROUGH SUPPORT OF RENEWABLES
}

\author{
Dalia Štreimikienè \\ Mykolas Romeris University, \\ Vilnius, Lithuania \\ E-mail:_dalia@mail.lei.lt \\ ORCID 0000-0002-3247-9912
}

Received: May, 2020

1st Revision: December, 2020

Accepted: March, 2021

DOI: $10.14254 / 2071-$

789X.2021/14-1/6

\begin{abstract}
Moving to $100 \%$ renewables scenario in EU requires huge support to renewable energy technologies, however this support needs to integrate positive externalities of renewables, therefore it is important to analyse dynamics of external costs of electricity generation in Visegrad countries and to compare them with support allocated to renewable energy sources in these countries. Therefore, the paper aims to compare the Visegrad countries in terms of reduction of external electricity generation costs due to increased share of renewables in electricity generation and the government support provided for renewables. ExternE methodology and CASES database is applied in this research. The results of study provide guidance for policy makers with regards to promotion of RES for achieving low-carbon energy transition by 2050 .
\end{abstract}

Keywords: external costs of electricity generation, renewable energy sources, public support to renewables, Visegrad countries.

\section{Introduction}

The main policy in the energy sector is to ensure sustainable energy development. Sustainable energy development can be ensured by dealing with important energy market failures hampering transition towards sustainable energy future. Energy market failures such as externalities, information asymmetry, inequality of income, etc. do not allow achieving environmental and social targets of sustainable energy development. Policies and measures targeting energy market failures can provide for achievement of sustainable energy development goals (Rafaj, Kypreos, 2007). The main policies and measures to overcome energy market failures can be grouped in the following way: promotion of renewable energy sources as life cycle external costs of energy generation by renewables are significantly lower than for fossil fuels (Bento et al., 2020). Therefore, internalization of external energy costs can be achieved by integrating external benefits of renewable energy sources linked to lower pollution and avoided GHG emissions during the usage of renewables (Lu et al., 2019; Savitz, Gvarilitea, 2019). These policies can be grouped into subsidies and other fiscal instruments, voluntary information and technical assistance etc. (Redondo, Collado, 2014; Liao et al., 2019). 
The main energy market failure is energy externalities. Therefore, assessment of externalities and integration of them via policy tools allows promoting sustainable energy development (Lu et al., 2020; Nagaj, 2020).

Therefore, energy-generating technologies have varying external costs in terms of atmospheric pollution (Ortega-Izquierdo, del Rio, 2016). Renewables have quite low such costs, while major damages linked to atmospheric pollution, adverse health and environmental effects including various climate change impacts are related to fossil fuel based power generation that are, at the same time, not reflected in the prices of electricity produced with fossil fuels. So, in order to internalize the external costs of fossil fuel based power generation, the EU has introduced a wide range of policy documents to support the penetration of renewables and to achieve low carbon energy transition and $100 \%$ renewables scenarios by 2050 (European Commission, 2020). These policies are supported by many regions, and not only European ones (Kasperowicz et al., 2017). Although the EU Member States prepared the National energy and climate plans (NECP) to support low-carbon energy transition in order to achieve energy and climate targets set for 2050, the implementation of support measures for renewables are not analysed in terms of integration of external energy generation costs though these policies aim directly at dealing with externalities.

The paper aims to overcome this gap and analyses the development of external costs in power generation due to penetration of renewables and moving towards low carbon future in the selected group of the EU countries and compares these costs in their dynamics with support for renewables in these countries during the same period. Such comparative assessment of several similar countries in terms of geographical, political and economic situation allows revealing the influence of external costs' internalization by promoting renewables on development of external costs in power generation.

The article is organised as follows. Section 1 presents the literature review; Section 2 introduces data and methods; Section 3 presents the results and discusses avenues for further research. Finally, section 4 concludes.

\section{Literature review}

Externalities are related with costs or benefits generated by an economic activity that are not taken into account by the parties involved in the activity (Krupnik \& Burtraw, 1996). As it widely accepted that atmospheric pollution linked by electricity generation at fossil fuel fired power plants has negative impact on environment and people, the government aims to introduce policies to control externalities and to force producers to internalize them in the costs of electricity generation by forcing consumers tom pay higher price for electricity produced from polluting fossil fuels and by this way to reduce its consumption. If consumer of electricity produced by fossil fuels does not pay these external costs, nor compensates people for damage done to them, they do not face the full cost of the services they purchase (Klaasen \& Riahi, 2007). The externalities are due to the absence of fully defined property rights as clean air is public good. Though, this situation can be changed by establishing property rights, however, it is not possible to do this in most case (Mishchuk et al., 2018) and cause shifts in well-being (Bilan et al., 2020). The possible corrective device can be a Pigouvian tax equal to marginal social damage for externality. If the tax collected for such damage is applied for the compensation of people suffering from this damage - externality is "internalised" (Samadi, 2017). For power generation, the externality can be generally assessed in EURct per $\mathrm{kWh}$ of electricity produced (Streimkiene \& Alisauskaite-Seskiene, 2016).

The evaluation of externality involves a requirement for substantial expertise. In energy sector, a life cycle approach must be applied for quantifying external costs of power generation 
(Karkour et al., 2020). There are many receptors that may be affected by power generation of various options including life cycle external costs of fuel chains.

There are several important categories of energy externalities ranging from external costs of environmental pollution, climate change to energy security etc. (Rabl \& Spadaro, 2016). There are various valuation methodologies for assessing environmental externalities. However, conventional markets do not exist for assessing damage of human health, ecological systems, etc. Such techniques as assessment of Willingness to Pay (WTP) or Willingness to Accept (WTA) compensation for usage of such "goods," be divided into assessment of external costs of atmospheric emissions of pollutants with local and with global impacts (Murakami et al., 2020). In fossil fuel chain the main stage causing atmospheric pollution and damage to environment and human health is power generation stage for fossil fuels. For renewable energy sources the main stage of atmospheric pollution is equipment manufacturing stage. It is necessary to stress, that all damage estimates are dominated by costs arising from negative influence on human health. This negative effect is directly linked to the density of population affected. Assessment of external health costs is mainly based on use of exposure- response epidemiological studies. The big problem is quantification in monetary terms of human health impacts. It is also obvious, that sparsely populated countries usually have low health damage costs. The ExternE study has assessed external human health costs for the coal fuel chain to be in range from 0.2 euro/kWh to 4.0 euro $/ \mathrm{kWh}$ (ExternE, 2020). For the natural gas fuel chain, for example combined cycle gas turbine generates few times lower external costs per $\mathrm{kWh}$. The largest damages occur in densely populated areas (European Commission, 1999; 2006). Rabl and Spadaro (2016) provided that under "typical" average European conditions, external costs makes about 5 euro/kWh for the coal fuel chain, and for natural gas -about 1 euro/kWh.

Studies provided that external costs resulting from combustion of fossil fuels, if internalised into power generation costs could lead to fast penetration of renewable energy technologies becoming competitive with fossil fuels (Ortega \& del Rio, 2013; Kilinic-Ata, 2016; Sansyzbayeva, et al., 2020). However, natural gas based combined cycle technology has financial advantage over other fuels under current market conditions. However, as the costs of renewables are declining constantly due to achievements in R\&D and economies of scale. Therefore, due to economies of scale, renewable energy-based technologies will obtain social cost advantage comparing to fossil fuel-based generation if the externalities of power generation are fully "internalised." The punishing of dirty power generation technologies provides incentives for clean renewable energy technologies and also promotes energy efficiency measures and reduce GHG emissions and other pollutants per unit of power generation output. The main measures of internalization of negative externalities are carbon, fossil fuel taxes and GHG emission charges. The removal of both direct and indirect subsidies for fossil fuel based power generation technologies and increasing the price of fossil (and nuclear) based power to address negative externalities of power generation are essential policies for promoting the development of renewable energy sources (Bento et al, 2020), as well as its positive consequences for employment increase in green economy (Okuneviciute Neverauskiene \& Rakauskiene, 2018). Though, the integration of external costs of power generation into the electricity tariff will serve for low carbon energy transition (Streimikiene \& AlisauskaiteSeskiene, 2016), however also support for renewable in term of subsidies or internalization of external benefits of these technologies is necessary. Therefore, the justification of energy subsidies for renewable energy technologies is fully justified to ensure fast market penetration of renewables and reduce market barriers for low carbon technologies.

In 1991 European Commission and US Department of Energy initiated common research project on assessment of environmental externalities of energy supply. A large number of world researchers of different disciplines joined this project. The modelling the full 'impact pathway' of atmospheric pollutants from the power plant through their interactions with the 
environment to a physical measure of impact was performed. Also, the first attempt of monetary valuation of associated welfare losses was carried out. During first phase which continued more than 4 years (European Commission, 1999), the framework for the assessment of external costs of energy technologies — named ExternE was developed (ExternE, 2020). There were 50 teams from 15 countries in Europe involved in follow-up activities of the ExternE project. Seven major types of environmental damages were identified and quantified within ExternE methodology in the first stage: human health (fatal and non-fatal effects), effects on crops and materials and other impacts were assessed (Bickel, Friedrich, 2005). The impact pathway approach and EcoSense model was developed within the ExternE project and applied for several studies ranging from 1991 to 2009 (NEEDS, 2008).

\section{Methods and data}

The evolution of external costs of power generation in Visegrad countries due to penetration of renewables with the state support provided for renewables in V4 group of countries will be performed base on ExternE methodology and Cases (2008) database.

The impact pathway approach and EcoSense model was applied in Cases (2008) project and energy externalities were assessed for all EU countries. Impact pathway assessment is based on bottom-up-approach tracking the pathway from the source of atmospheric emissions via changes of air, soil and water to physical impacts. The average height of release was applied. External costs are available for emission of NH3, NMVOC, NOX, PPMco, PPM25, SO2 for all EU member states. It was assumed in Cases (2008) that in most cases the atmospheric emissions in 2020 are lower than in 2010 due to non-linear atmospheric chemistry and $\mathrm{f}$ different background concentrations of NOx and NMVOC, ozone. Even negative external costs were assessed for NOx emission due to ozone. The values have been derived by simulation of a certain emission reduction in different regions.

In Table 1 external costs of atmospheric pollutants emission from power sector are provided in 2010 and 2020 for Visegrad countries based on CASES project results (CASES, 2008).

Table 1. External costs of atmospheric pollutants from power sector of Visegrad countries in 2010 and 2020 (Cases, 2008), EUR2005/t

\begin{tabular}{|c|c|c|c|c|c|}
\hline Country & EU average & Czech Republic & Slovakia & Poland & Hungary \\
\hline \multicolumn{6}{|c|}{2010} \\
\hline \multicolumn{6}{|c|}{ Human health costs } \\
\hline $\mathrm{NH}_{3}$ & 9,482 & 16,783 & 15,094 & 9,651 & 13,672 \\
\hline NMVOC & 584 & 584 & 163 & 452 & 483 \\
\hline NOx & 5,591 & 7,302 & 7,856 & 5,344 & 7,150 \\
\hline PPMco & 1,325 & 1,009 & 842 & 1,185 & 667 \\
\hline $\mathrm{PPM}_{25}$ & 24,410 & 25,208 & 21,640 & 25,201 & 16,411 \\
\hline $\mathrm{SO}_{2}$ & 6,070 & 7,235 & 6,696 & 6,451 & 6,485 \\
\hline \multicolumn{6}{|c|}{ Loss of Biodiversity } \\
\hline $\mathrm{NH}_{3}$ & 3,266 & 5,079 & 5,227 & 3,865 & 3,180 \\
\hline NMVOC & -67 & -83 & -56 & -54 & -49 \\
\hline NOx & 903 & 1,341 & 1,077 & 1,036 & 1,086 \\
\hline $\mathrm{SO}_{2}$ & 177 & 399 & 332 & 223 & 283 \\
\hline \multicolumn{6}{|c|}{ Crops $\mathrm{N}$ regional deposition } \\
\hline $\mathrm{NH}_{3}$ & -183 & -126 & -129 & -96 & -167 \\
\hline NMVOC & 189 & 138 & 93 & 114 & 86 \\
\hline NOx & 328 & 399 & 458 & 238 & 393 \\
\hline $\mathrm{SO}_{2}$ & -27 & -43 & -20 & -10 & -15 \\
\hline \multicolumn{6}{|c|}{ Crops $\mathrm{SO}_{2}$} \\
\hline $\mathrm{SO}_{2}$ & -13 & -14 & -6 & -4 & -5 \\
\hline
\end{tabular}




\begin{tabular}{|c|c|c|c|c|c|}
\hline \multicolumn{6}{|c|}{ Materials $\mathrm{SO}_{2} \& \mathrm{NOx}$} \\
\hline NOx & 71 & 127 & 163 & 132 & 178 \\
\hline $\mathrm{SO}_{2}$ & 258 & 498 & 469 & 497 & 487 \\
\hline \multicolumn{6}{|c|}{2020} \\
\hline \multicolumn{6}{|c|}{ Human health costs } \\
\hline $\mathrm{NH}_{3}$ & 5,837 & 10,719 & 9,200 & 5,615 & 8,952 \\
\hline NMVOC & 238 & 151 & 102 & 131 & 129 \\
\hline NOx & 6,620 & 10,106 & 10,718 & 6,909 & 9,354 \\
\hline PPMco & 1,381 & 1,040 & 845 & 610 & 639 \\
\hline $\mathrm{PPM}_{25}$ & 24,191 & 23,992 & 22,057 & 14,498 & 16,285 \\
\hline $\mathrm{SO}_{2}$ & 6,673 & 8,747 & 7,598 & 7,746 & 6,485 \\
\hline \multicolumn{6}{|c|}{ Loss of Biodiversity } \\
\hline $\mathrm{NH}_{3}$ & 3,295 & 5,273 & 5,482 & 3,990 & 3,300 \\
\hline NMVOC & -48 & -72 & -48 & -48 & -42 \\
\hline NOx & 868 & 1,280 & 987 & 1,014 & 984 \\
\hline $\mathrm{SO}_{2}$ & 192 & 418 & 343 & 258 & 306 \\
\hline \multicolumn{6}{|c|}{ Crops $\mathrm{N}$ regional deposition } \\
\hline $\mathrm{NH}_{3}$ & -183 & -126 & -132 & -98 & -170 \\
\hline NMVOC & 103 & 62 & 45 & 55 & 39 \\
\hline NOx & 435 & 448 & 428 & 295 & 451 \\
\hline $\mathrm{SO}_{2}$ & -41 & -75 & -39 & -42 & -36 \\
\hline \multicolumn{6}{|c|}{ Crops $\mathrm{SO}_{2}$} \\
\hline $\mathrm{SO}_{2}$ & -13 & -14 & -6 & -1 & -5 \\
\hline \multicolumn{6}{|c|}{ Materials $\mathrm{SO}_{2} \& \mathrm{NOx}$} \\
\hline NOx & 71 & 127 & 163 & 131 & 178 \\
\hline $\mathrm{SO}_{2}$ & 259 & 498 & 469 & 524 & 487 \\
\hline
\end{tabular}

Source: created by author based on (Cases, 2008)

As one can see from Table 1, Czech Republic distinguishes with the highest external health costs following Slovakia and Hungary.

External costs of power generation per technology were obtained from CASES database and provided in Table 2. Cases (2008) database on external costs for electricity generation technologies was developed for all EU Member States for 2010, 2020 and 2030, the external costs of power generation for 2010-2018 period for Visegrad were assessed by employing average values of external costs of power generation for 2010 and 2020 taken from CASES database.

The external costs of power generation in Visegrad countries in 2010-2020 used in further analysis are given in Table 2 .

Table 2. Average external costs of power generation in Visegrad countries in 2010-2020, EURct/kWh

\begin{tabular}{ccccc}
\hline & Czech Republic & Slovakia & Poland & Hungary \\
\hline Coal & 4.60 & 4.53 & 4.32 & 4.66 \\
\hline Oil & 8.31 & 8.29 & 7.04 & 7.19 \\
\hline Gas & 2.12 & 2.12 & 2.02 & 2.18 \\
\hline Hydro & 0.22 & 0.22 & 0.20 & 0.24 \\
\hline Wind & 0.15 & 0.16 & 0.14 & 0.15 \\
\hline Biomass & 6.28 & 6.20 & 5.81 & 6.16 \\
\hline Biogas & 4.85 & 4.84 & 4.76 & 4.90 \\
\hline Solar & 0.63 & 0.61 & 0.58 & 0.64 \\
\hline Waste & 7.01 & 6.93 & 6.44 & 6.16 \\
\hline Nuclear & 0.57 & 0.56 & 0.55 & 0.57 \\
\hline
\end{tabular}

Source: created by author based on (Cases, 2008) 
In next section of paper comparative assessment of external costs of power generation dynamics in Visegrad countries will be performed based on dynamics of power generation structure of these countries obtained from EUROSTAT database (EUROSTAT, 2020). The assessment of external costs of power generation results will be compared with dynamics of state support for renewables during the same period.

\section{Discussion of results}

In order to perform comparative assessment of Visegrad countries the dynamics of electricity generation structure and the increase of the share of renewables needs to be assessed to track progress of countries towards low carbon energy transition.

Electricity generation structure in Visegard countries is provided in Figures1-4.

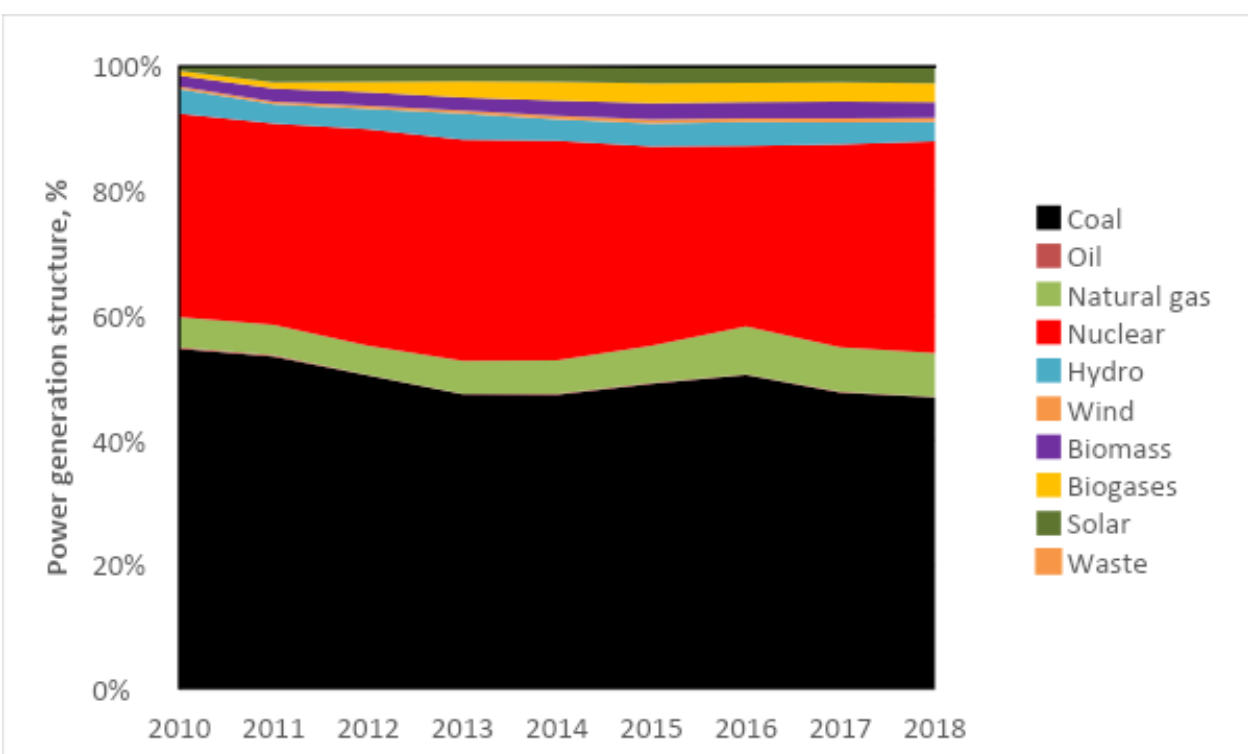

Figure 1. Dynamics of power generation structure in Czech Republic during 2010-2018 Source: prepared by author based on (EUROSTAT, 2020)

As one can notice from Figure 1, the coal makes almost $50 \%$ of power generation structure according fuels in Czech Republic and there are insignificant changes in increase of the share of renewables in power generation balance during investigated period though the share of coal is slightly decreasing, the share of nuclear and natural gas is almost stable. 


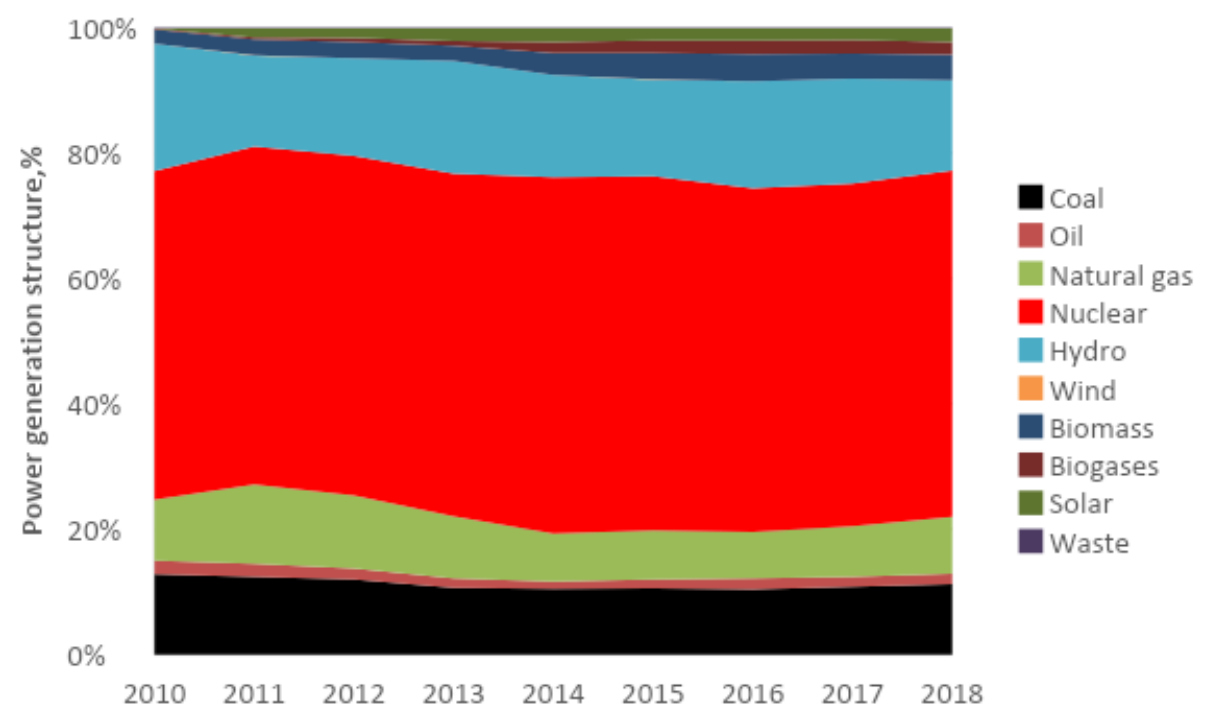

Figure 2. Dynamics of power generation structure in Slovakia during 2010-201 Source: prepared by author based on (EUROSTAT, 2020)

Information given in Figure 2, shows that the share of nuclear makes more than the 50\% in power generation structure in Slovakia during investigated period and the share of renewables is increasing very slowly. The share of coal and natural gas was also almost stable during investigated period.

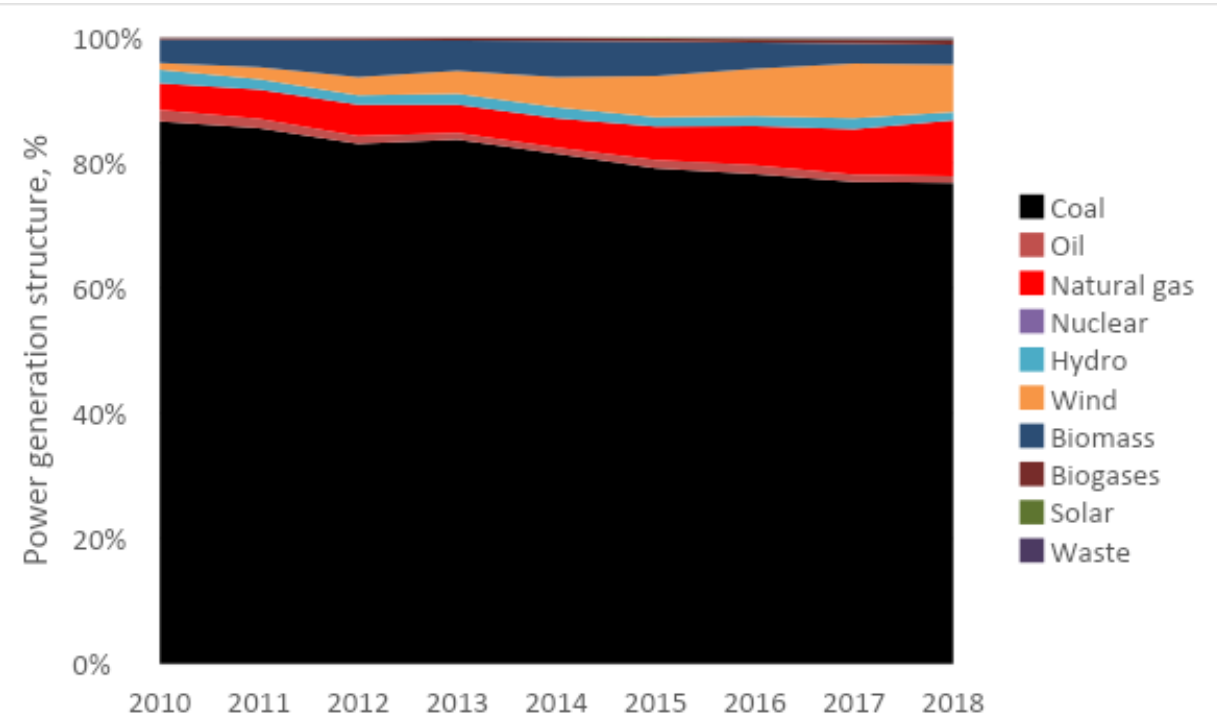

Figure 3. Dynamics of power generation structure in Poland during 2010-2018 Source: prepared by author based on (EUROSTAT, 2020)

The dynamics of electricity generation structure provided in Figure 3 shows the decrease of coal in electricity generation structure of Poland during investigated period. The increase of the share of renewable energy sources, especially wind, can be noticed though coal is still dominating electricity generation structure in Poland. 


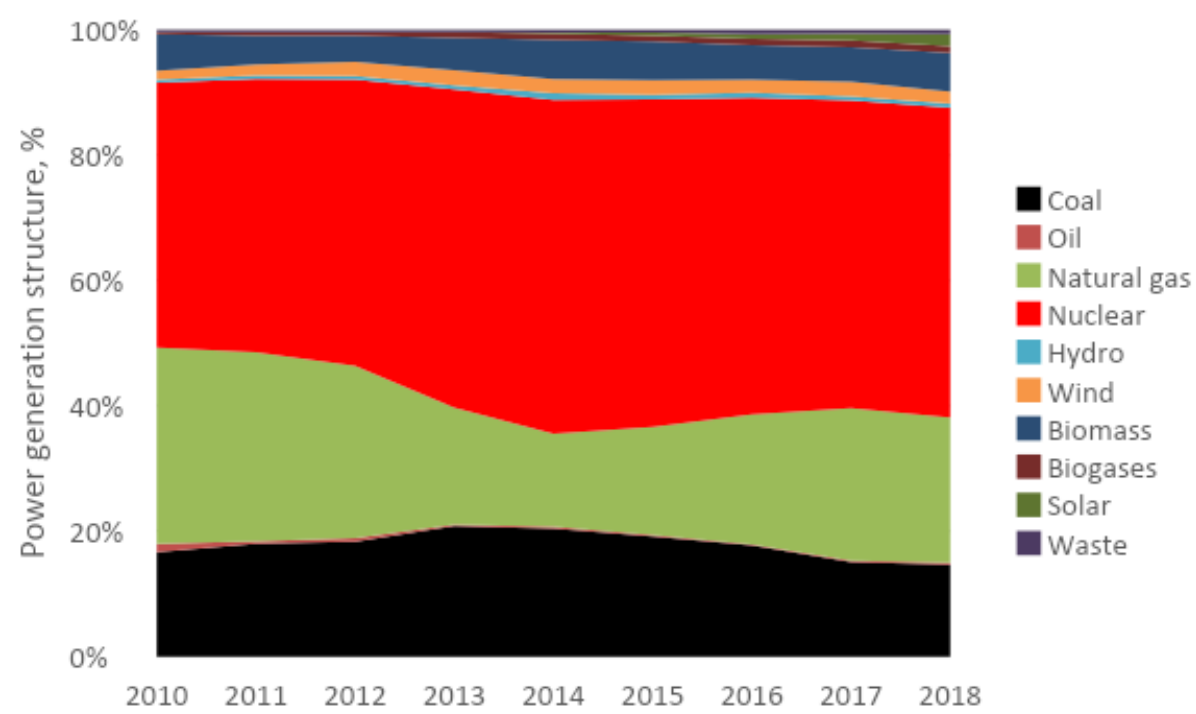

Figure 4. Dynamics of power generation structure in Hungary during 2010-2018 Source: prepared by author based on (EUROSTAT, 2020)

Information on dynamics of power generation structure in Hungary provided in Figure 4 reveals the decrease of the share of coal however the share of renewables has increased insignificantly during investigated period and the share of nuclear was also quite stable in Hungary during investigated period.

Further, based on the power generation structure of Visegrad countries in 2010-2018 and average external costs of power generation in Visegrad countries in 2010-2020 given in Table 2, the dynamics of external costs of power generation in Visegrad countries is assessed in Table 3.

Table 3. Dynamics of external costs of power generation in Visegrad countries during 20102018, million EUR

\begin{tabular}{|c|c|c|c|c|c|c|c|c|c|}
\hline Fuels & 2010 & 2011 & 2012 & 2013 & 2014 & 2015 & 2016 & 2017 & 2018 \\
\hline \multicolumn{10}{|c|}{ Czech Republic } \\
\hline Coal & 215.74 & 214.77 & 202.31 & 189.11 & 187.36 & 189.24 & 193.06 & 190.62 & 189.52 \\
\hline Oil & 0.62 & 0.53 & 0.34 & 0.25 & 0.34 & 0.28 & 0.28 & 0.37 & 0.34 \\
\hline Natural gas & 8.90 & 8.99 & 8.63 & 9.79 & 9.77 & 10.52 & 13.53 & 13.06 & 12.97 \\
\hline Nuclear & 16.80 & 16.97 & 18.19 & 18.45 & 18.20 & 16.10 & 14.46 & 17.00 & 17.95 \\
\hline Hydro & 0.74 & 0.59 & 0.63 & 0.80 & 0.65 & 0.68 & 0.70 & 0.67 & 0.59 \\
\hline Wind & 0.05 & 0.06 & 0.06 & 0.07 & 0.07 & 0.09 & 0.08 & 0.09 & 0.09 \\
\hline Biomass & 9.61 & 11.12 & 11.93 & 11.12 & 13.06 & 13.69 & 13.63 & 14.63 & 13.94 \\
\hline Biogases & 3.06 & 4.51 & 7.13 & 11.11 & 12.51 & 12.66 & 12.56 & 12.80 & 12.66 \\
\hline Solar & 3.91 & 13.73 & 13.55 & 12.79 & 13.36 & 14.24 & 13.42 & 13.80 & 14.87 \\
\hline Waste & 0.21 & 0.49 & 0.42 & 0.42 & 0.49 & 0.56 & 0.56 & 0.63 & 0.56 \\
\hline Total & 259.43 & 271.26 & 262.77 & 253.48 & 255.32 & 257.49 & 261.71 & 263.05 & 262.94 \\
\hline $\begin{array}{l}\text { Average per } \\
\text { EURct/kWh }\end{array}$ & 3.02 & 3.10 & 3.01 & 2.92 & 2.97 & 3.07 & 3.15 & 3.03 & 2.99 \\
\hline \multicolumn{10}{|c|}{ Slovakia } \\
\hline Coal & 16.17 & 16.08 & 15.49 & 13.91 & 13.00 & 12.82 & 12.68 & 13.54 & 13.64 \\
\hline Oil & 4.97 & 4.89 & 4.23 & 3.56 & 2.49 & 3.15 & 3.90 & 3.65 & 3.81 \\
\hline Natural gas & 5.77 & 7.70 & 7.08 & 6.04 & 4.45 & 4.47 & 4.22 & 4.71 & 5.15 \\
\hline Nuclear & 8.16 & 8.63 & 8.68 & 8.80 & 8.68 & 8.48 & 8.27 & 8.44 & 8.31 \\
\hline Hydro & 1.24 & 0.91 & 0.98 & 1.14 & 0.98 & 0.91 & 1.01 & 1.02 & 0.85 \\
\hline
\end{tabular}




\begin{tabular}{|c|c|c|c|c|c|c|c|c|c|}
\hline Wind & 0.00 & 0.00 & 0.00 & 0.00 & 0.00 & 0.00 & 0.00 & 0.00 & 0.00 \\
\hline Biomass & 3.91 & 4.40 & 4.65 & 4.34 & 5.83 & 6.94 & 7.19 & 6.82 & 6.76 \\
\hline Biogases & 0.15 & 0.53 & 0.92 & 1.02 & 2.32 & 2.61 & 2.81 & 2.86 & 2.61 \\
\hline Solar & 0.01 & 0.24 & 0.26 & 0.36 & 0.37 & 0.31 & 0.32 & 0.31 & 0.36 \\
\hline Waste & 0.14 & 0.21 & 0.21 & 0.14 & 0.21 & 0.21 & 0.14 & 0.21 & 0.14 \\
\hline Total & 40.52 & 43.60 & 42.49 & 39.31 & 38.33 & 39.92 & 40.55 & 41.56 & 41.64 \\
\hline $\begin{array}{l}\text { Average per } \\
\text { EURct/kWh }\end{array}$ & 1.46 & 1.52 & 1.49 & 1.37 & 1.40 & 1.49 & 1.51 & 1.51 & 1.55 \\
\hline \multicolumn{10}{|c|}{ Poland } \\
\hline Coal & 589.72 & 603.76 & 581.34 & 594.95 & 559.53 & 563.85 & 562.98 & 566.61 & 564.02 \\
\hline Oil & 20.35 & 17.25 & 14.43 & 12.53 & 11.19 & 14.92 & 16.19 & 14.22 & 12.67 \\
\hline Natural gas & 1.35 & 1.54 & 1.64 & 1.48 & 1.49 & 1.78 & 2.11 & 2.49 & 3.05 \\
\hline Nuclear & 0.00 & 0.00 & 0.00 & 0.00 & 0.00 & 0.00 & 0.00 & 0.00 & 0.00 \\
\hline Hydro & 0.70 & 0.55 & 0.49 & 0.60 & 0.55 & 0.49 & 0.52 & 0.61 & 0.48 \\
\hline Wind & 0.23 & 0.45 & 0.67 & 0.84 & 1.08 & 1.52 & 1.76 & 2.09 & 1.79 \\
\hline Biomass & 34.34 & 41.54 & 55.37 & 46.07 & 53.22 & 52.46 & 40.26 & 31.32 & 31.49 \\
\hline Biogases & 1.90 & 2.14 & 2.71 & 3.28 & 3.90 & 4.33 & 4.90 & 5.24 & 5.38 \\
\hline Solar & 0.00 & 0.00 & 0.00 & 0.00 & 0.01 & 0.03 & 0.07 & 0.10 & 0.17 \\
\hline Waste & 0.32 & 0.19 & 0.19 & 0.19 & 0.32 & 0.52 & 1.35 & 2.00 & 2.83 \\
\hline Total & 648.91 & 667.43 & 656.85 & 659.95 & 631.28 & 639.91 & 630.16 & 624.66 & 621.88 \\
\hline $\begin{array}{l}\text { Average per } \\
\text { EURct/kWh }\end{array}$ & 4.12 & 4.08 & 4.05 & 4.01 & 3.97 & 3.88 & 3.78 & 3.67 & 3.66 \\
\hline \multicolumn{10}{|c|}{ Hungary } \\
\hline Coal & 29.03 & 30.20 & 29.54 & 29.36 & 27.96 & 26.98 & 26.24 & 22.97 & 21.76 \\
\hline Oil & 3.52 & 1.01 & 1.37 & 0.58 & 0.58 & 0.58 & 0.43 & 0.65 & 0.65 \\
\hline Natural gas & 25.53 & 23.67 & 20.82 & 12.27 & 9.50 & 11.40 & 14.41 & 17.44 & 16.13 \\
\hline Nuclear & 8.98 & 8.94 & 9.00 & 8.76 & 8.92 & 9.02 & 9.15 & 9.18 & 8.97 \\
\hline Hydro & 0.05 & 0.05 & 0.05 & 0.05 & 0.07 & 0.06 & 0.06 & 0.05 & 0.05 \\
\hline Wind & 0.08 & 0.09 & 0.12 & 0.11 & 0.10 & 0.10 & 0.10 & 0.11 & 0.09 \\
\hline Biomass & 13.43 & 10.16 & 8.87 & 9.61 & 11.33 & 11.52 & 10.72 & 11.15 & 12.07 \\
\hline Biogases & 0.59 & 1.03 & 1.03 & 1.32 & 1.42 & 1.42 & 1.62 & 1.72 & 1.62 \\
\hline Solar & 0.00 & 0.00 & 0.01 & 0.01 & 0.04 & 0.09 & 0.15 & 0.22 & 0.40 \\
\hline Waste & 0.92 & 0.80 & 0.74 & 0.62 & 0.74 & 0.86 & 1.29 & 1.23 & 1.36 \\
\hline Total & 82.13 & 75.96 & 71.54 & 62.69 & 60.67 & 62.03 & 64.17 & 64.73 & 63.09 \\
\hline $\begin{array}{l}\text { Average per } \\
\text { EURct/kWh }\end{array}$ & 2.20 & 2.11 & 2.07 & 2.07 & 2.07 & 2.05 & 2.02 & 1.97 & 1.98 \\
\hline
\end{tabular}

Source: created by author based on (Cases, 2008; EUROSTAT, 2020)

In Figure 5 the dynamics of weighted average external costs per $\mathrm{kWh}$ of power generation in Visegrad countries is provided. The Poland distinguishes with the highest external costs of electricity generation among Visegrad group countries and this is easy to understand knowing the high share of coal in power generation structure. Czech Republic is second country according the level of external costs of power generation. 


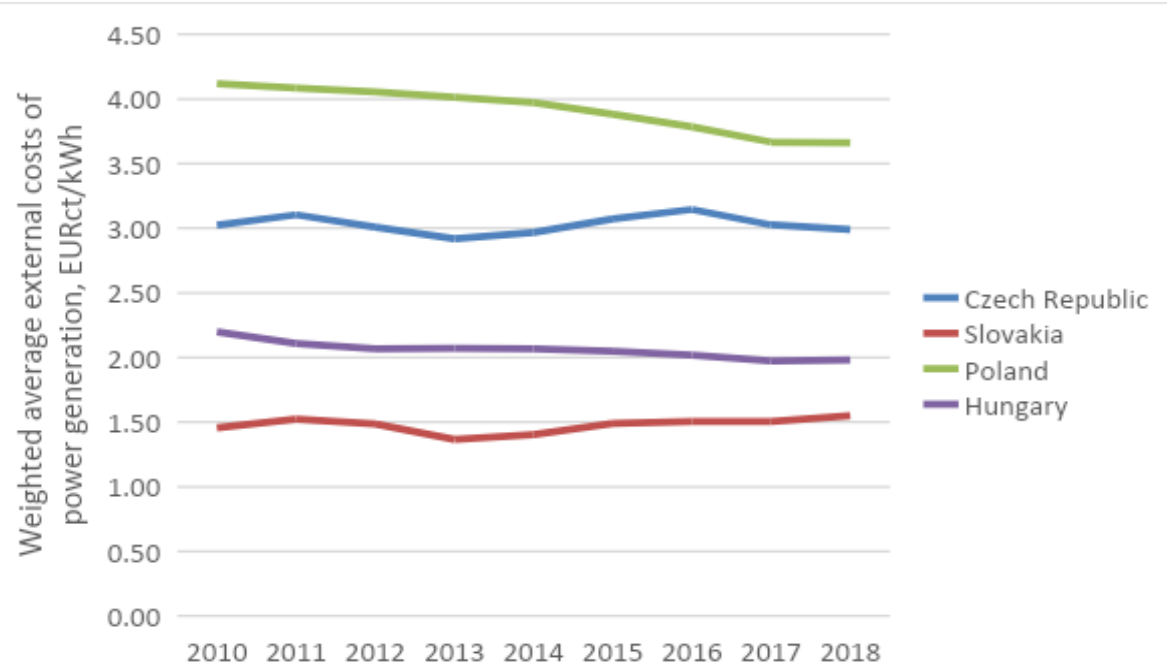

Figure 5. Dynamics of weighted average external costs per $\mathrm{kWh}$ of power generation in Visegrad countries

Source: created by author

As one can see from Figure 5 due to penetration of renewables average external costs of power generation were declining significantly just in Poland and Hungary during investigated period. In Czech Republic and Slovakia the average weighted external costs of power generation were almost stable during the same period.

The dynamics of public support for renewables in Visegrad countries is provided in Table 4.

Table 4. Evolution of public support to renewables in Visegrad countries during 20122017, EURct/kWh

\begin{tabular}{|c|c|c|c|c|c|c|c|c|}
\hline $\begin{array}{c}\text { Power } \\
\text { generation } \\
\text { technologies }\end{array}$ & 2010 & 2011 & 2012 & 2013 & 2014 & 2015 & 2016 & 2017 \\
\hline \multicolumn{9}{|c|}{ Czech Republic } \\
\hline Solar & 43.6 & 43.2 & 46.2 & 44.8 & 42.6 & 43.8 & 46.5 & 47.9 \\
\hline Hydro & 4.5 & 5.7 & 5.2 & 5.7 & 6.4 & 6.8 & 7.7 & 8.1 \\
\hline Wind & 4.2 & 6.4 & 6.6 & 7.5 & 7.8 & 7.8 & 8.5 & 8.7 \\
\hline Biomass & 5.2 & 5.1 & 9.9 & 10.2 & 9.2 & 9.3 & 10.4 & 10.5 \\
\hline Biogas & 11.8 & 10.8 & - & - & - & - & - & - \\
\hline Total & 5.1 & 19.6 & 22.0 & 19.5 & 17.8 & 18.4 & 19.7 & 19.8 \\
\hline \multicolumn{9}{|c|}{ Poland } \\
\hline Solar & - & - & 6.9 & 7.1 & 7.2 & 7.2 & 2.9 & 1.7 \\
\hline Hydro & - & - & 6.9 & 7.1 & 7.2 & 7.2 & 2.9 & 1.7 \\
\hline Wind & - & - & 6.9 & 7.1 & 7.2 & 7.2 & 2.9 & 1.7 \\
\hline Biomass & - & - & 6.9 & 7.1 & 7.2 & 7.2 & 2.9 & 1.7 \\
\hline Total & - & - & 6.9 & 7.1 & 7.2 & 7.2 & 2.9 & 1.7 \\
\hline \multicolumn{9}{|c|}{ Hungary } \\
\hline Solar & - & - & 5.4 & 6.6 & 6.5 & 6.4 & 6.7 & 5.3 \\
\hline Hydro & 7.4 & 7.2 & 1.6 & 3.2 & 3.1 & 3.0 & 3.4 & 1.9 \\
\hline Wind & 10.6 & 11.2 & 5.8 & 7.1 & 7.1 & 7.1 & 7.5 & 6.2 \\
\hline Biomass & 10.5 & 11.3 & 5.7 & 6.9 & 7.1 & 7.0 & 7.3 & 6.2 \\
\hline Biogas & 10.3 & 11.0 & - & - & - & - & - & - \\
\hline Total & 10.2 & 10.7 & 5.3 & 6.6 & 6.6 & 6.6 & 6.9 & 5.8 \\
\hline
\end{tabular}

Source: created by author based on (CEER, 2018) 
As one can see from Table 4 Czech Republic distinguished with very high level of support for renewable energy sources per $\mathrm{kWh}$, though in this country the average weighted external costs of power generation were almost stable during the same period showing that support provided to renewables has not allowed to achieve fast penetration of renewable energy sources. In addition, the average weighted external costs in 2018 were about 3 EURct $/ \mathrm{kWh}$ and average weighted public support to renewables was almost $20 \mathrm{EURct} / \mathrm{kWh}$ in Czech Republic in the same year showing unwarranted support to renewables in the country.

In Poland the average weighted public support to renewables in 2018 made just 1.7 EURct/kWh and average weighted external costs of electricity generation were approximately twice higher than support, i. e. 3.7 EURct/kWh. Therefore, the public support level for renewables is low comparing with external costs of electricity generation (Tomaszewski \& Sekściński, 2020).

In Hungary the average weighted public support to renewables in 2018 made about 6 EURct/kWh in 2018 and the average weighted external costs of power generation were almost 2 EURct/kWh in the same year showing quite high levels of support for renewables.

In Figure 6 the dynamics of weighted average support level for renewables per $\mathrm{kWh}$ in Visegrad countries is provided

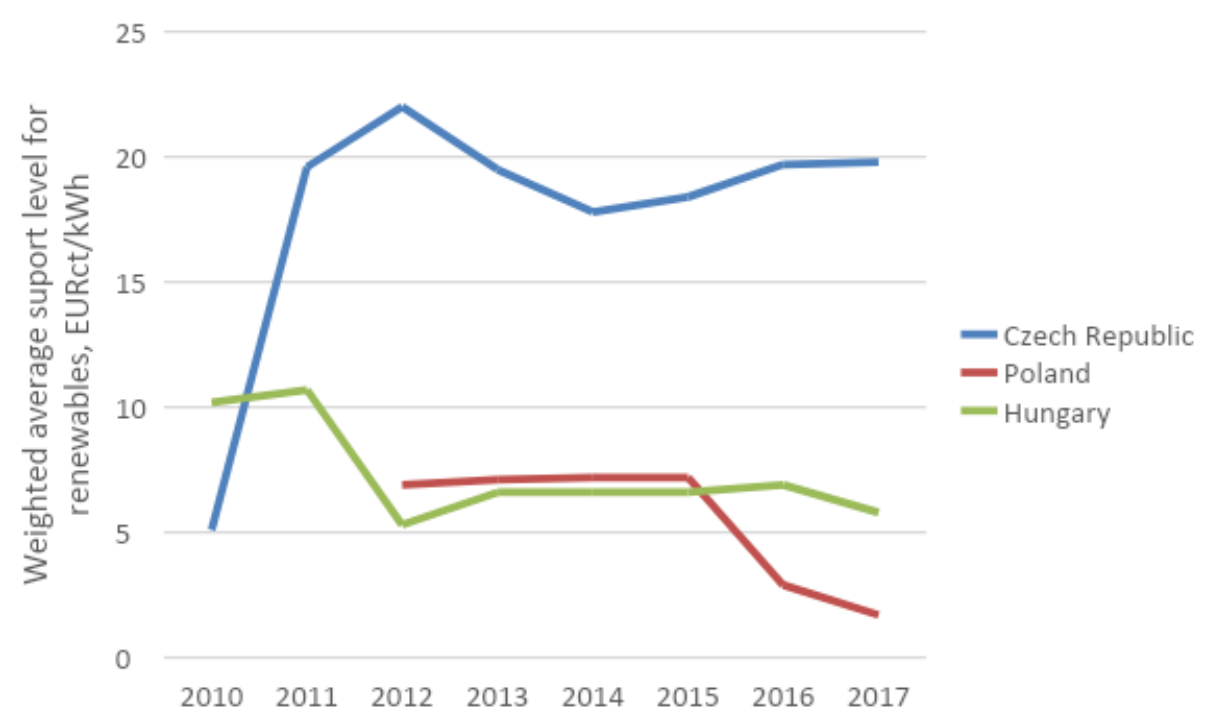

Figure 6. Dynamics of weighted average support level for renewables per kWh in Visegrad countries

Source: created by author

As one can see from information provided in Figure 6, Visegrad countries distinguish with different weighted average level of support per kWh for renewables and quite different trends. In Hungary and Poland clear reduction trend of weighted average support for renewables can be noticed however in Czech Republic having ten times higher support level than in Poland the trend of weighted average support level increase can be noticed.

The performed comparative analysis of dynamics of external costs of power generation and public support for renewables in Visegrad countries provided interesting results in terms of state efforts to promote renewables. Though all these countries are EU member states and have implemented similar EU energy and environmental policy documents the public support levels and their impacts on penetration of renewables are very different. These issues need to be analysed in more details to provide answers for such big differences in public support, 
especially considering current trends of consumers environment responsibility (Holotová et al., 2020).

\section{Conclusions}

External costs of power generation indicate the negative environmental impact of power generation which is necessary to take internalize in order to ensure fast penetration of renewables in energy markets. This internalization can be achieved in two ways - by taxing fossil fuel generators or by providing public support to renewables or in both ways.

The comparative assessment of trends in external power generation costs and public support to renewables in Visegard countries provided that though the share of renewables in power generation has increased since 2004 however since 2010 the Visegrad countries achieved slow progress and public support for renewables was very different in these countries.

Analysis of dynamics of weighted average external costs per $\mathrm{kWh}$ of power generation in Visegrad countries provided that Poland distinguishes with the highest external costs of electricity generation among Visegrad group countries due to very high share of coal in power generation structure following the Czech Republic.

Due to penetration of renewables the average external costs of power generation were declining significantly just in Poland and Hungary during 2010-2018. In Czech Republic and Slovakia the average weighted external costs of power generation were almost stable during the same period.

The analysis of dynamics of public support level for renewables in Visegard countries revealed that Czech Republic distinguishes with very high level of support for renewable energy sources per $\mathrm{kWh}$ - almost $20 \mathrm{EURct} / \mathrm{kWh}$ though average weighted external costs of power generation in the same year were about 3 EURct $/ \mathrm{kWh}$. In addition, the average weighted external costs of power generation were almost stable during 2010-2018 showing that support provided to renewables has not allowed to achieve fast penetration of renewable energy sources.

Poland distinguishes with low average weighted public support for renewables which accounted just to 1.7 EURct/kWh in 2018 though the average weighted external costs of electricity generation were approximately twice higher and made almost 4 EURct $/ \mathrm{kWh}$. Therefore, the public support level for renewables in Poland was low comparing with external costs of electricity generation.

In Hungary the average weighted public support to renewables made about 6 EURct/kWh in 2018 and the average weighted external costs of power generation were almost 2 EURct/kWh in the same year showing quite high levels of support for renewables.

Overall, the performed comparative analysis of dynamics of external costs of power generation and public support for renewables in Visegrad countries provided that though all these countries are EU member states and have implemented similar EU energy and environmental policy documents the public support levels and their impacts on penetration of renewables are very different. These issues need to be analysed in more details to provide answers for such big differences in public support and reasoning of this. 


\section{References}

Bento, N., Borello, M., \& Gianfrate, G. (2020). Market-pull policies to promote renewable energy: A quantitative assessment of tendering implementation. Journal of Cleaner. Production, 248, 119209.

Bickel, P., \& Friedrich, R. (2005). ExternE externalities of energy methodology 2005 update. Available online: http://www.externe.info/externe_2006/brussels/methup05a.pdf (accessed on 2 October 2020).

Bilan, Y., Mishchuk, H., Samoliuk, N., \& Yurchyk, H. (2020). Impact of Income Distribution on Social and Economic Well-Being of the State. Sustainability, 12(1), 429; doi:10.3390/su12010429

Bilan, Y., Nitsenko, V., \& Havrysh, V. (2017). Energy aspect of vertical integration in agriculture. Rynek Energii, 132(5), 98-110.

CASES. (2008). D.06.1 Database of Full costs for EU, with external and private costs. Available online: http://www.feem-project.net/cases/downloads_deliverables.php (accessed on 2 October 2020).

CEER. (2018). Status review of renewable and energy efficiency support schemes in Europe in 2016 and 2017. Available online: https://www.ceer.eu/documents/104400/-/-/80ff31278328-52c3-4d01-0acbdb2d3bed (accessed on 11 January 2020).

European Commission. (1999). ExternE externalities of energy. Vol.1: Summary; Vol.2: Methodology; Vol.3: Coal and Lignite; Vol.4: Oil and Gas; Vol.5: Nuclear; Vol.6: Wind and Hydro. Available online: https://portals.iucn.org/library/node/22494 (accessed on 5 October 2020).

European Commission. (2006). ExternE volume 10 national implementation. Available online: http://www.externe.info/externe_d7/sites/default/files/vol10.pdf (accessed on 2 October 2020).

ExterneE. (2020) ExterneE - External Costs of Energy. Available online http://www.externe.info/externe_d7 (accessed on 10 October 2020).

European Commission. (2020). 2030 Energy Strategy. Available online: https://ec.europa.eu/energy/en/topics/energy-strategy-and-energy-union/2030-energystrategy (accessed on 5 October 2020).

Eurostat. (2020) Energy database. Available online: https://ec.europa.eu/eurostat/web/energy/data/database (accessed on 10 October 2020).

Holotová, M., Nagyová, L., \& Holota, T. (2020). The impact of environmental responsibility on changing consumer behaviour - sustainable market in Slovakia. Economics and Sociology, 13(3), 84-96. doi:10.14254/2071-789X.2020/13-3/6

Karkour, S., Ichisugi, Y., Abeynayaka, A., \& Itsubo, N. (2020). External-Cost estimation of electricity generation in G20 Countries: Case Study using a global life-cycle impactassessment method. Sustainability, 12, 200.

Kasperowicz, R., Pinczyński, M., \& Khabdullin, A. (2017). Modeling the power of renewable energy sources in the context of classical electricity system transformation. Journal of International Studies, 10(3), 264-272. doi:10.14254/2071-8330.2017/10-3/19

Kilinc-Ata, N. (2016). The evaluation of renewable energy policies across EU countries and US states: An econometric approach. Energy for Sustain Development, 31, 83-90.

Klaasen, G., \& Riahi, K. (2007). Internalizing externalities of electricity generation: An analysis with MESSAGE-MACRO. Energy Policy, 35, 815-827.

Krupnick, A. J., \& Burtraw, D. (1996). The social costs of electricity: Do the numbers add up? Resource and. Energy Economics, 18, 423-466. 
Mishchuk, H., Samoliuk, N., Bilan, Y., \& Streimikiene, D. (2018). Income inequality and its consequences within the framework of social justice. Problemy Ekorozwoju, 13(2), 131138.

Murakami, K., Itsubo, N., Kuriyama, K., Yoshida, K., \& Tokimatsu, K. (2018). Development of weighting factors for $\mathrm{G} 20$ countries. Part 2: Estimation of willingness to pay and annual global damage cost. International Journal of Life Cycle Assessment, 23, 2349-2364.

Liao, H., Long, Y., Ming, T., Mardani, A., \& Xu, J. (2019). Low carbon supplier selection using a hesitant fuzzy linguistic span method integrating the analytic network. Transformations in Business and Economics, 18 (2(47)), 67-88.

Lu, J., Ren, L., Yao, S., Rong, D., Skare, M., \& Streimikis, J. (2019). Renewable energy barriers and coping strategies: Evidence from the Baltic States. Sustainable Development, 28, 352-367.

Lu, J., Zhang, C., Ren, L., Liang, M., Strielkowski, W., \& Streimikis, J. (2020). Evolution of External Health Costs of Electricity Generation in the Baltic States. International Journal of Environmental Research and Public Health, 17, 52-65. https://doi.org/10.3390/ijerph17155265.

Nagaj, R. (2020). Climate and energy policies and its impact on energy poverty in Poland. Rynek Energii, 146(1), 1-10.

NEEDs. (2008). External costs from emerging electricity generation technologies. Deliverable $\mathrm{n}^{\circ}$ 6.1-RSla, sustainable energy systems. Available online: http://www.needsproject.org/docs/RS1a\%20D6_1\%20External\%20costs\%20of\%20reference\%20technol ogies\%2024032009.pdf (accessed on 4 October 2020).

Okuneviciute Neverauskiene, L., \& Rakauskiene, O. G. (2018). Identification of employment increasing possibilities in the context of the EU socioeconomic environment evaluation: The case of Lithuania. Economics and Sociology, 11(4), 51-68. doi:10.14254/2071789X.2018/11-4/3

Ortega-lzquierdo, M, \& del Rio, P. (2016). Benefits and costs of renewable electricity in Europe. Renewable and Sustainable Energy Reviews, 61, 372-383.

Ortega, M., del Rio, P., \& Montero, E.A. (2013). Assessing the benefits and costs of renewable electricity. The Spanish case. Renew Sustain Energy Reviews, 27, 294-304.

Rabl, A., \& Spadaro, J.V. (2016). External costs of energy: How much is clean energy worth? J. Solar Energy Engineering, 138, 1-8.

Rafaj, P., \& Kypreos, S. (2007). Internalisation of external cost in the power generation sector: Analysis with Global Multi-regional MARKAL model. Energy Policy, 35, 828-843.

Redondo, A.J.G., \& Collado, R.R. (2014). An economic valuation of renewable electricity promoted by feed-in system in Spain. Renewable Energy, 68, 51-57.

Sansyzbayeva, G., Temerbulatova, Z., Zhidebekkyzy, A., \& Ashirbekova, L. (2020). Evaluating the transition to green economy in Kazakhstan: A synthetic control approach. Journal of International Studies, 13(1), 324-341. doi:10.14254/2071-8330.2020/13-1/21

Savitz, R., \& Gavriletea, M.D. (2019). Climate change and insurance. Transformations in Business \& Economics, 18, 1 (46), 21- 43.

Streimikiene, D., \& Alisauskaite-Seskiene I. (2016). Comparative Assessment of External Costs and Pollution Taxes in Baltic States, Czech Republic and Slovakia. Ekonomie A Management, XIX, 4, 4-18. doi:10.15240/tul/001/2016-4-001.

Tomaszewski, K., \& Sekściński, A. (2020). Renewable energy sources in Poland - Local and regional perspective. Rynek Energii, 149(4), 10-19. 